\title{
O PRINCÍPIO DA FUNÇÃO SOCIAL DA PROPRIEDADE NA ZONA DE CONFLITO JURÍDICO-POLÍTICO: UMA CONTRIBUIÇÃO AO DEBATE ACERCA DA PROBLEMÁTICA URBANA CONTEMPORÂNEA
}

\author{
Luiz Antônio Evangelista de Andrade* \\ Universidade Federal de Minas Gerais
}

\begin{abstract}
Resumo: Há uma renitente negativa, de boa parte do Judiciário brasileiro, em aplicar o postulado contido no princípio constitucional da função social da propriedade. A observância do mérito das contendas em torno das utilizações da propriedade fundiária vem privilegiando a sua dimensão civilista, em detrimento da sua natureza social. Em face daquela negativa, nas metrópoles brasileiras têm sido intensas as reivindicações dos movimentos sociais de luta pela moradia, cujo fito é o de fazer cumprir tal princípio constitucional, bem como de seus dispositivos, regulamentados no Estatuto da Cidade. Uma das chaves de interpretação dessas decisões do Judiciário é que a função social da propriedade é uma categoria jurídica e política que expressa teórica e idealmente os pilares da economia política. Atendo-se a esse pressuposto, assim como ao fato de que a propriedade fundiária, nos últimos 30 ou 40 anos, assumiu uma importância renovada na dinâmica da acumulação e da urbanização brasileira, há diversas implicações sobre a reflexão e as reivindicações em torno do cumprimento daquele mesmo princípio. E a historicidade da formação da moderna propriedade e dos debates sobre sua função social, dentro e fora do Brasil, são cruciais no entendimento daquelas implicações.
\end{abstract}

Palavras-chave: Propriedade fundiária. Função social da propriedade. Renda fundiária. Ambiente construído urbano.

THE PRINCIPLE OF SOCIAL FUNCTION OF PROPERTY ON THE LEGAL-POLITICAL RING: A CONTRIBUTION TO DISCUSSIONS ABOUT CONTEMPORARY URBAN PROBLEMS

Abstract: There is an intransigent refusal, from a good part of Brazilian Judiciary, to apply the postulate from the constitutional principle of social function of property. The observance of the merit of strivings about the uses of land properties has been focusing on their civil rights dimension, rather than the social one. On the other hand, in Brazilian major cities, the demands of the Housing Policy social movements, whose the main order is to enforce this constitutional principle, as well as its provisions, regulated in the Statue of the City. One of the keys to interpret those judicial decisions is that the social function of property is a legal and political category which represents theoretically and ideally the pillars of political economy. Based on this premise likewise on the fact that, in the last 30 or 40 years, land properties renewed their importance in the accumulation dynamics and in Brazilian urbanization, there are several implications for reflection about and claims around the implementation of that same principle. And both the historicity of the modern property formation and the debates about its social function, inside and outside Brazil, are crucial to understand those implications.

Keywords: land property. Social function of property. Land rent. Built urban environment.

\section{EL PRINCIPIO DE LA FUNCIÓN SOCIAL DE LA PROPRIEDAD EN LA ZONA DE CONFLICTO JURIDICO-POLITICO: UNA CONTRIBUCIÓN AL DEBATE} SOBRE LA PROBLEMÁTICA URBANA CONTEMPORÁNEA

Resumen: Hay un obstinado rechazo, de buena parte del Poder Judicial brasileño, en aplicar el postulado contenido en el principio constitucional de la función social de la propiedad. La observancia del fondamento de las disensiones en torno a los usos de la propiedad de la tierra viene privilegiando su aspecto civilista, en detrimento de su naturaleza social. Por otro lado, en las metrópolis brasileñas han sido intensas las reivindicaciones de los movimientos sociales de lucha por la vivenda, cuya finalidad es el de hacer cumplir dicho principio constitucional, así como de sus prescripciones juridicas, reguladas en el Estatuto de la Ciudad. Una de las claves de interpretación de estas decisiones judiciales es que la función social de la propiedad es una categoría jurídica y política que expresa teórica e idealmente los pilares de la economía política. Teniendo e cueta a este presupuesto, así como al hecho de que la propiedad territorial, en los últimos 30 o 40 años, ha ganado una importancia renovada en la dinámica de la acumulación y de la urbanización brasileña, hay varias implicaciones sobre la reflexión y las reivindicaciones en torno al cumplimiento de aquel mismo principio. Y la historicidad de la formación de la moderna propiedad y de los debates sobre su función social, dentro y fuera de Brasil, son fundamentales en el entendimiento de aquellas implicaciones.

Palabras-clave: Propiedad territorial. Función social de la propiedad. Renta del suelo. Espacio urbano construido. 
Introdução

Diversos autores nas ciências sociais e jurídicas têm discutido sobre a insistência de boa parte do Judiciário brasileiro em negar a aplicação do postulado jurídico contido no princípio constitucional da função social da propriedade, com o intento de se resolver as contendas relacionadas às utilizações da propriedade fundiária, tanto na realidade agrária quanto nas grandes centralidades urbanas ${ }^{1}$. De acordo com a maior parte desses autores, a observância dessas contendas, por parte dos juízes, seria perpassada por um forte caráter civilista orientador de suas decisões, o qual levaria em conta tão somente a forma "pura" da lei. De tal sorte que as posições desses magistrados quanto àquelas mesmas contendas estaria levando à redução das contradições sociais do capitalismo a uma soma de conflitos individuais.

Ao mesmo tempo, ganham amplitude as reivindicações dos movimentos sociais versados com a luta pela moradia $^{2}$ e balizados por diferentes frentes de apoio, exigindo que se cumpra aquele princípio constitucional, bem como os instrumentos jurídico-urbanísticos que ordenam sua regulamentação, contidos no Estatuto da Cidade. De acordo com a maioria desses grupos, urge que se garanta a utilização da propriedade fundiária consoante ao "interesse público", privilegiando-o em face dos "interesses individuais", expressos pelo fenômeno que, comumente, é denominado "especulação imobiliária" por tais grupos.

O pressuposto que orientará nossa argumentação ao longo deste ensaio é que a função social da propriedade deve ser entendida como uma categoria jurídica e política que, em última instância, é a expressão teórica e ideal da economia política. Desse modo, a função social da propriedade, na medida em que encontra suas determinações nas formas sociais do valor e da mercadoria, não é uma categoria jurídica trans-histórica, isto é, só pode ser efetivamente compreendida nas conexões que possui com as relações sociais de produção que engendraram a moderna propriedade privada capitalista. Por isso, o caráter histórico presente da propriedade - do qual sobressaem os conflitos por suas utilizações - nos diz muito sobre o seu caráter histórico passado.

Uma questão central permeará este ensaio: tendo-se em conta que a propriedade privada, particularmente em sua forma fundiária, notadamente nos últimos 30 ou 40 anos, assumiu uma importância renovada na dinâmica da acumulação capitalista e da urbanização brasileira, que implicações esse fato tem para a reflexão e as reivindicações em torno do cumprimento do princípio constitucional da função social da propriedade?

Para um apanhado acerca desse posicionamento do Judiciário brasileiro, ver Tarso de Melo (2012).

Particularmente o Movimento de Luta nos Bairros, Vilas e Favelas (MLB), a Comissão Pastoral da Terra (CPT) e as Brigadas Populares (BPS). Este último, em particu-

lar, possui várias frentes de atuação política, tais como a antiprisional, de mulheres e da juventude, não se restringindo à luta pela moradia.
Balizado por tal pressuposto e tal questão, o presente ensaio está repertoriado em cinco momentos de análise, encadeados entre si.

1) Um breve excurso sobre a formação da propriedade privada capitalista e a sua justificação jurídica como um direito absoluto, atendo-nos às suas reverberações nos debates surgidos no âmbito da economia política do século XIX, particularmente as formulações surgidas sob a pena do filósofo e economista inglês John Stuart Mill.

2) Os limites teóricos e categoriais dessas formulações na compreensão do papel exercido pela propriedade (na sua forma fundiária) na reprodução de relações sociais de produção e, em particular, para a compreensão dos significados da função social da propriedade como categoria jurídica e política advinda da economia política.

3) Uma rápida apresentação acerca da efetividade jurídica do princípio da função social da propriedade na Europa e no Brasil e a quadra histórica em que isso ocorreu.

4) Valendo-nos da realidade empírica da "região do Isidoro" ${ }^{3}$, lócus de um sério conflito pelas utilizações da propriedade fundiária em Belo Horizonte, discutiremos os impasses e limites das reivindicações dos movimentos sociais de luta pela moradia em torno do cumprimento da função social da propriedade, quando ancoradas no argumento da "especulação imobiliária", a qual, supostamente, há décadas vem ocorrendo na área.

5) Teceremos algumas considerações sobre a estratégia a seguir pelos movimentos sociais de luta pela moradia, mormente no debate sobre a função social da propriedade.

A moderna propriedade fundiária capitalista em seu triplo movimento: formação, absolutização e relativização

Pode-se afirmar que o longo e conflituoso descolamento da propriedade territorial das suas formas tribais e comunais, verificado no Ocidente europeu, faz parte das raízes históricas do processo de acumulação econômica ali verificado. Estamos falando do progressivo processo - que depois se tornaria mais abrupto e violento - de separação dos produtores diretos das suas condições objetivas de produção, processo esse narrado de modo magistral por Marx (1998 [1867]), no capítulo XXIV do Livro I de O Capital (Acumulação primitiva). Somente através dessa forma histórica específica a propriedade poderia vir a se tornar uma condição fundante para a passagem da subsunção formal à subsunção real

"Para não gerar confusão no leitor, utilizaremos a designação "região do Isidoro", embora ela seja denominada pelos movimentos de luta pela moradia que atuam na área como região "da Izidora", após as possíveis origens da denominação terem sido descobertas, em fins do ano de 2014. De acordo com a professora Margarete Leta, da Associação dos Arquitetos Sem Fronteira - Brasil, nos mapas de Belo Horizonte publicados até 1937, o ribeirão que dava nome à região era grafado como ribeirão da Izidora. Segundo Margarete, quando teve a oportunidade de conhecer o quilombo Mangueiras, situado na região, foi-Ihe dito que Izidora teria sido uma escrava (ou uma mulher escravizada) alforriada que ali constituiu sua descendência. 
do trabalho ao capital, viabilizando, sob a forma do valor excedente, a produção da riqueza social como valor que se autovaloriza (capital).

Para Marx, não seria possível explicar o desencadeamento da acumulação do capital recorrendo-se a uma lenda teológica, tampouco a transformando numa lenda econômica. A concentração dos meios de produção e da riqueza não é o resultado da perspicácia previdente da formiga face à indolência da cigarra, isto é, a aparição de uma "...elite [que] foi acumulando riquezas..." ao lado de uma "...população vadia que ficou finalmente sem ter outra coisa para vender além da própria pele" (MARX, 1998 [1867], L. I, V. 2, p. 835). O pressuposto para se desvendar a acumulação é o processo histórico (e social) que a produz, com seus avanços e recuos, revelando, no seu desenrolar, fenômenos ora mais abruptos, ora mais lentos.

Assim sendo, a forma moderna da propriedade privada, considerando-se aqui o processo de subjetivação gerado no esteio das relações sociais de propriedade, processo que fez dela um "para si na consciência", afırmara Marx (2004 [1844]), não se explica apenas por um argumento de fundo moral, isto é, um sentido que corresponderia, por exemplo, ao "consumo individual egoísta". De fato, esse comportamento se desenvolve no próprio processo de subjetivação. 0 que queremos assinalar aqui, contudo, encontra seus nexos nas relações de produção e de circulação que presidem as trocas mercantil-capitalistas, tendo inscrito historicamente a propriedade na mobilização para a produção da riqueza sob a forma valor. De modo que essa mobilização encontra sua legitimidade nas relações políticas e jurídicas enquanto referências das relações de propriedade, sem as quais a apropriação privada da riqueza produzida sob a forma valor não alcançaria seus fins na sociedade burguesa.

É precisamente no interior da relação da propriedade privada que outra relação, a dos homens e mulheres consigo mesmos, com os outros e com a natureza externa assume a sua maior alienação ${ }^{4}$. Ao mesmo tempo, a propriedade se objetiva nas relações sociais de produção de maneira fetichizada, posta como ápice da liberdade individual. E é sob a forma sujeito de direito, expressão idealizada da condição social de proprietário de mercadorias, que os indivíduos aparecem como iguais que manifestam livremente suas "vontades interiores" e estipulam contratos que as façam valer.

De tal sorte que a economia política e a ciência jurídica, cada uma a seu modo, põem a "coisa exterior" (a propriedade privada), sobre a qual se direciona a "von-

\footnotetext{
${ }^{4}$ Todavia, Marx (2011 [1857-8]) assinalou que a alienação já figurava, por exemplo, no espectro das relações sociais feudais, onde a propriedade territorial, pelo fato de ser detida pelos Senhores, colocava-se como algo estranhado do homem servil, forma objetiva dele independente. E essa forma de propriedade, como não poderia deixar de ser, seria o fundamento histórico e social da propriedade privada capitalista. A propriedade feudal tinha um significado bastante distinto daquele que a define por dentro da produção de riqueza material ou de bem adquirido a partir do pensamento e da prática utilitaristas, os quais só conseguem concebê-la para a extração da renda fundiária capitalizada - ou, como ainda enfatizaremos, enquanto "bem financeiro puro".
}

tade interior", como expressão materializada daquela liberdade individual, invertendo uma relação que é, em verdade, a submissão dos indivíduos à coisa - que nada mais é do que a sujeição do trabalho ao capital, lócus do desenvolvimento da relação da propriedade privada. Aquilo que Friedrich Hegel (1997 [1820]) via como sendo a positividade da exteriorização (a propriedade privada), Marx (2004 [1844]) via na sua negatividade: "o objeto que o trabalho produz, o seu produto, se lhe defronta como um ser estranho, como um poder independente do produtor" (p. 80, grifos do autor).

As modalidades modernas da apropriação da riqueza produzida como capital, quando observadas apenas nas suas formas fenomênicas, aparecem como resultado de uma igualdade (jurídica) que perpassa as relações nas quais se envolvem tais indivíduos na produção daquela riqueza social. A cada um caberia "sua parte no latifúndio", separada entre si e distinta, mas amparada pela "justiça" dos homens: ao proprietário de capital caberia o lucro; ao trabalhador, o salário; e aos proprietários fundiários caberia a renda fundiária. Quanto a estes últimos, dediquemo-los um apreço específico, posto que serve aos nossos propósitos de discutir o instituto da função social da propriedade.

Classe social formada historicamente pelos destroços dos antigos senhores feudais e dos antigos colonos de que falou Marx (2011 [1857-8]) e resultante da expropriação da propriedade das suas determinações pré-modernas, esses proprietários passaram a deter a prerrogativa de reter para si parte dessa riqueza social sob moldes distintos da época anterior. Dito de outro modo, a partir das novas determinações da propriedade, tornada um direito absoluto e exclusivo, a retenção de parte dessa riqueza social, sob a forma de renda fundiária absoluta ou até frações das rendas diferenciais futuras, passou a independer dos usos efetivos da propriedade.

Essa prerrogativa de retenção ensejou, por parte de alguns economistas do século XIX, formulações acusatórias acerca de sua atitude "parasitária" frente à riqueza socialmente produzida, visto que não contribuiriam efetivamente na sua produção. Tais acusações, promovidas sob a forma de debates econômicos e políticos, foram encimadas por posições simpáticas à relativização daquele que era um direito absoluto de propriedade, atentando para a necessidade de que esta viesse a ter uma "função social". Vejamos, em linhas gerais, alguns dos argumentos trazidos por essas posições, através daquele que poderíamos denominar como um de seus mais importantes formuladores: o filósofo e economista inglês John Stuart Mill'5.

\footnotetext{
5Vale dizer que a argumentação de Stuart Mill não traz o conteúdo jus-filosófico que caracterizou as argumentações de alguns juristas em fins do século XIX e que formaram o assoalho para a presença do instituto da função social da propriedade nas constituições das primeiras décadas do século XX. Entre esses juristas podemos citar o francês Léon Duguit, cujas elaborações visaram desfazer o caráter absoluto do
} direito de propriedade, constante no Código Civil Francês de 1804 (LEONETTI, 1999). 
Stuart Mill pode ser considerado um autor bem peculiar no interior da escola clássica da economia política, haja vista que suas formulações transitavam, como assinalou Isaac Rubin (2014 [1989]), a meio caminho entre o liberalismo clássico e o socialismo. Um dos desejos do autor inglês, conforme escrevera no prefácio à terceira edição (1852) dos Princípios de economia política com algumas de suas aplicações à filosofia social, originalmente lançado em 1848, era o de combinar aquilo que ele chamava de liberdade pessoal com uma "distribuição justa dos frutos do trabalho", aspecto que as "leis da propriedade privada", dadas pela sua absolutização, não previam (STUART MILL, 1996 [1848], p. 55). Essa peculiaridade levou Stuart Mill a uma resoluta oposição às afirmações dos economistas que desqualificavam antecipadamente as propostas "socialistas". Ao mesmo tempo, e diante do que julgava serem dificuldades concretas para se verificar as "vantagens do socialismo" em relação à sociedade de seu tempo, algo por ele considerado não só viável como desejável, notadamente no que concernia às utilizações da propriedade privada, Mill propugnou reformas sociais abrangentes no "sistema de propriedade individual". E isso de modo que "os membros da comunidade" tivessem plena participação nos benefícios oriundos das produções.

Nos Princípios da economia política..., em particular na sua Parte Segunda, dedicada à "Distribuição", Mill traz de maneira mais acabada a discussão em torno da propriedade fundiária como elemento primaz da circulação, numa implicação do que ele entendia serem as suas bases: o caráter social da produção de mercadorias e do seu suporte, o trabalho. No capítulo que versa sobre a "Propriedade" e sobre a necessidade de diferenciar os "bens móveis" dos "bens imóveis", o autor expõe suas constatações acerca da realidade fundiária da Inglaterra de seu tempo, dentro da qual o arrendatário seria aquele que propiciava as melhorias na terra - e não a pessoa do proprietário. Estabelecendo comparações entre o norte e o sul do país, onde, nesta última região, pelo fato de a racionalidade que torna a propriedade um fator de produção ainda não se fazer presente, as técnicas empregadas na terra não eram as mais apuradas. Por consequência, os "níveis de produtividade" do sul eram bem menores que os do norte.

Assim, se a produtividade da terra advém do trabalho humano, e que, para se alcançar tal produtividade, seriam necessários investimentos dispendiosos a curto prazo - com taxas de retorno que seguiriam uma proporção temporal muito mais lenta -, Mill argumentou que tais investimentos seriam inibidos ou até mesmo inviabilizados, caso os resultados do trabalho continuassem a ser colhidos por outros que não aqueles que empreenderam na terra. $O$ autor chegou a atribuir aos proprietários fundiários a culpa pelas crises de fome na Irlanda, vez que estes, ao tomarem para si toda a produção, acabavam por consumi-la conspicuamente, sem devolver ao solo aquilo que sua terra produziu através do trabalho de outrem.

Por que, então, não relativizar a propriedade fundiária - questionou-se Stuart Mill -, com o intuito de ampliar a capacidade produtiva inglesa e de instar os proprietários fundiários a aplicarem corretamente seu capital na terra, de modo a se lidar com as "inconveniências" da má apropriação da produção e da "injustiça" dela decorrente? $\mathrm{E}$ mais: a inviolabilidade da propriedade fundiária deveria deixar de ser uma premissa jurídica e o seu título deveria pertencer a quem empreende na terra, a quem a melhora e a torna mais produtiva ${ }^{7}$. Estando a propriedade fundiária e o direito dos proprietários atados à "política geral do Estado", cumpriria a este intervir nas propriedades onde a observância da produção não fosse consoante aos "critérios sociais assumidos". Assim, privilegiar-se-ia o "interesse da comunidade" - dizia Mill - em detrimento do "interesse individual mesquinho" dos proprietários. E isso, porquanto:

\begin{abstract}
O princípio da propriedade não lhes confere [aos proprietários fundiários] direito algum sobre a terra, mas apenas um direito à compensação por qualquer porção própria de interesse que tenham na terra, e da qual a política do Estado possa vir a privá-los. (...) [Mas] o Estado tem o poder de tratar a propriedade fundiária conforme possam exigir os interesses da comunidade até o ponto - se tal acontecer - de fazer em relação à área total aquilo que se faz em relação à porção dela quando se aprova uma lei para a construção de uma ferrovia ou de uma nova rua. (STUART MILL, 1996 [1848], p. 290)
\end{abstract}

Não carece fazer um grande exercício de abstração para percebermos os intentos contidos na argumentação de Stuart Mill e de outros economistas (vulgares ou não) que se contorceram para justificar que a propriedade, ao contrário de ser a forma social engendradora da proletarização e da monetarização das relações sociais, bem como do estranhamento e da alienação próprios à natureza do trabalho social, garantiria a satisfação individual e, por consequência, o "interesse coletivo". De fato, o economista em apreço estava diante das dificuldades postas a uma sociedade na qual a ordem econômica, embora fosse capaz de desenvolver sobremaneira as forças produtivas, não conseguia transformá-las em desenvolvimento social efetivo. Como sublinhou Rubin (2014 [1989]), o utopismo burguês e iluminista de uma sociedade - a capitalista - capaz de propiciar, além de bem-estar material, a igualdade e a fraternidade universais, estava diante da concretude da mais abjeta miséria vivida pela maior parte da população cuja venda de

\footnotetext{
6"O interesse da comunidade está por demais envolvido no cultivo adequado da terra e nas condições de ocupação da mesma, para deixar tais coisas ao critério de uma classe de pessoas denominadas senhores da terra, quando demonstraram não merecer tal confiança" (STUART MILL, 1996 [1848], p. 289).

${ }^{7}$ De acordo com Stuart Mill (1996 [1848]), "Quando a propriedade chegou a esse pé [a baixa produtividade e a apropriação dos "frutos do trabalho" pelos proprietários fundiários], deixa de ser defensável, e chegou o momento de implantar algumas medidas" (p. 288-9).
} 
sua força de trabalho era o único recurso para garantir a mera sobrevivência.

Sensível a esses resultados, ao mesmo tempo em que sua formação em economia o fazia crer na suposta racionalidade, imutabilidade e eternidade de suas leis, Stuart Mill buscou dar uma solução idealizada às situações concretas da maior parte da população das cidades industriais inglesas. Daí a sua ideia de que as leis da produção, ao passo que deveriam funcionar sem amarras estatais, rompendo com os impedimentos à sua plena realização, deveriam se combinar com leis de distribuição da riqueza que viabilizassem o bem-estar individual e social. Em outras palavras, as leis da produção, racionais, imutáveis e eternas, deveriam estar livres de quaisquer impedimentos à sua realização; já as leis da distribuição, contingentes e passíveis de receberem os aperfeiçoamentos morais de uma sociedade que se desenvolvia espiritualmente, deveriam ser deslocadas para garantir a satisfação social. Uma separação abstrata dada por categorias distintas (MARX, 2011 [1857-58], p. 42-43) - daquilo que era (e é) impossível de ser separado na realidade: a produção e a distribuição da riqueza sob o capitalismo. Eis o procedimento analítico metafísico que viria a ser bastante utilizado pelos socialistas (os "ricardianos", por exemplo) e que entraria numa enorme polêmica a partir de Marx e Engels.

Diferentemente daqueles ideólogos, preocupados apenas em constatar, descrever e contabilizar as condições e/ou os resultados palpáveis da produção social em si mesma, Marx dedicou-se a analisar criticamente a atividade produtora das mercadorias, isto é, por que, nessa atividade, a interação entre os indivíduos ocorria através das coisas, da forma social de valor assumida pelos produtos do seu trabalho. No desenvolvimento do capitalismo, comandante daquela atividade produtora, a todo momento seus agentes precisam lidar seja com os resquícios das relações sociais de produção que lhe são anteriores, seja com as próprias relações que não lhe servem enquanto tais. Resquícios e relações essas que, de acordo com as circunstâncias espaciais e temporais em que se põem diante dos agentes daquele processo, podem por ele ser absorvidos, redefinidos ou mesmo destruídos. Com a propriedade fundiária não é diferente. Sendo uma irracionalidade historicamente herdada, a propriedade, malgrado deva ser atualizada face à reprodução social capitalista, pode também se apresentar, na sua forma mais elementar, como importante momento da reprodução dessas relações - em verdade, na sua produção, através de novas acumulações primitivas. Vejamos essa questão mais de perto.

Marx, à sua época, compreendeu muito bem o importante papel que a propriedade passara a desempenhar no processo de desenvolvimento capitalista, em que pese naquele papel a preservação do seu caráter contraditório. O filósofo alemão trouxe as abordagens dos eco- nomistas políticos da escola clássica acerca da teoria da renda - expondo suas limitações e buscando superá-las teoricamente -, partindo da concretude da propriedade territorial no capitalismo e, mais especificamente, a propriedade na agricultura. As ilusões postas pela teoria econômica burguesa (de ontem e de hoje) costumam partir do fato dado e acabado da propriedade, com esta se apresentando naquilo que é o seu movimento necessário, embora não inaugural: como pressuposto da produção capitalista e da acumulação do capital. Porém, o ponto de partida é a produção da propriedade pelo capital, seja através da proletarização, seja a partir da produção da propriedade já na sua feição capitalista, como ocorreu nos Estados Unidos ou no Brasil.

Uma das questões primordiais de Marx, inclusive para demonstrar como operava a teoria do valor na agricultura, perpassava a compreensão de aspectos aparentemente triviais: o fato de a terra possuir um preço, ser transacionada no mercado, mas não trazer consigo valor representado, ou seja, não ser um produto do trabalho. 0 aspecto central, para Marx (1974 [1894]), seria o fato de que o interesse que movia os proprietários fundiários e os proprietários de capital nos negócios com a terra era o de liberá-la com o fito de receber renda fundiária, por parte dos primeiros, e, por parte dos últimos, de utilizá-la produtivamente para receber incrementos de renda e lucros.

A necessidade de Marx em circunscrever conceitualmente a renda fundiária como categoria teórica que distingue os proprietários de terra como classe social deu-se no esteio da sua constatação de que a produção da propriedade capitalista no Ocidente europeu supôs a transformação das formas pré-modernas da renda fundiária (feudais, extraídas em espécie através do trabalho servil na gleba) nas suas formas modernas, extraídas em dinheiro. No entender de Marx (1974 [1894]), foi essa transformação das rendas que permitiu o incremento sem precedentes do comércio, bem como da indústria urbana enquanto pressuposto da aceleração das modernas condições de produção de mercadorias e da circulação monetária. Foi a partir da possibilidade de se extrair renda fundiária monetária que se erigiu e pôde se generalizar um mercado de terras ancorado na compra e venda com tal fim, e também o arrendamento com vistas à extração de lucros sobre o capital investido na terra (HARVEY, 1990 [1982]).

Não que a privatização da propriedade territorial e a submissão do antigo produtor direto a um sistema de produção e troca de mercadorias tenha feito surgir, de maneira acabada, a propriedade privada capitalista. Como informa Harvey (1990 [1982]), podem surgir formas intermediárias de diversos tipos, embora estas não possam sobreviver por muito tempo, pois a produção de mercadorias deve incentivar o desenvolvimento das for- 
ças produtivas - mormente pela via de investimentos em ciência e tecnologia -, de modo a fomentar inovações de produtos, reduzir os preços de mercado e ampliar os mercados consumidores. A propriedade capitalista também exige uma organização dos processos de trabalho mais desenvolvida, do que resulta a possibilidade de extração de mais-valor relativo, contribuindo assim para uma maior organização da concentração dos capitais e a viabilização de investimentos mais vultosos.

Podemos afirmar que esses diversos tipos possíveis de formas intermediárias da propriedade capitalista foram percebidos por Stuart Mill; ainda assim, este autor não conseguiu ou não quis interpretar tal fenômeno sob o prisma da sua gênese histórica. E sob qual olhar o autor procedeu à explicação daquelas formas intermediárias? Ao criticar os "senhores da terra" por não participarem da produção de "melhorias na terra" e não se disporem a estudar as "melhorias científicas na agricultura", Stuart Mill procedia, como era do costume daqueles que se ocupavam dos temas econômicos de seu tempo, a uma abordagem circunscrita às formas fenomênicas da propriedade de terras ${ }^{8}$.

Quando as contradições concretas batem à porta, com a apropriação da terra (as formas intermediárias da propriedade) se tornando uma "inconveniência" (nos termos de Stuart Mill) e se colocando como um entrave aos investimentos que permitiriam, numa palavra, o aumento da "composição orgânica do espaço" (LEFEBVRE, 2008 [1972]) e a capitalização de rendas fundiárias, os economistas burgueses passaram a reivindicar medidas - cujas garantias deveriam advir do Estado - para corrigir as incongruências produzidas pela propriedade fundiária. 0 debate econômico e político trazido por esses economistas, em verdade, direcionava-se contra as restrições colocadas pela presença da renda absoluta (referida à baixa composição orgânica do espaço) em áreas enormes da Inglaterra e da Irlanda. O que, ao fim e ao cabo, levaria à necessidade de se transacionar no mercado produtos com preços de mercado acima dos preços de produção. Tratava-se, da parte de economistas como Stuart Mill, de exigir uma necessária atualização da propriedade fundiária frente aos processos espaciais - os quais nada mais eram do que a própria realidade urbana em ato - que estavam se desenrolando na Inglaterra como condição e resultado da expansão da indústria.

O que torna a discussão sobre o caráter parasitário

\footnotetext{
8Segundo Rubin ([1989] 2014), David Ricardo, em sua importante teoria da renda, acabou fazendo uma série de generalizações sobre o desenvolvimento da agricultura inglesa. Sua lei da "fertilidade decrescente do solo" acabou por levar o economista inglês a confundir as condições conjunturais daquela agricultura em seu tempo com uma suposta "tendência inexorável do desenvolvimento da agricultura", qual seja, a necessidade de se produzir nas piores terras. Por "consequência", os custos de produção seriam mais altos, levando ao aumento dos preços dos cereais e da renda fundiária a ser paga aos proprietários de terra. Além disso, os salários pagos na agricultura teriam de ser maiores e haveria no setor uma taxa decrescente de lucro. Tal equívoco não foi suplantado por Ricardo, visto que não estava presente em sua teoria a categoria renda absoluta - algo que Marx incorporaria em sua própria abordagem. Somente assim Ricardo compreenderia que as piores terras geram, sim, uma renda, embora o proprietário dessas terras preferisse deixá-las incultas a dá-las de graça a um agricultor para o cultivo (RUBIN, 2014 [1989]).
}

dos "senhores da terra" no século XIX completamente improcedente - haja vista que a negatividade da presença da propriedade fundiária, qual seja, a apropriação da renda fundiária por tais "senhores da terra" que, ao revés, se incorporaria aos lucros do capital, já que é parte do mais-valor, pode ser suplantado pela sua positividade se põe ao observarmos a própria presença da propriedade sob o capitalismo. Como bem desvela Harvey (1990 [1982]), apoiando-se em Marx, o proprietário de terras nada mais é do que a "personificação de uma das condições mais essenciais da produção". E é precisamente aí que do proprietário de terras é cobrado que ele assuma uma mentalidade proprietária moderna que possa nutrir esse atributo; que exerça apenas o "papel positivo"9 que ele pode vir a ter na reprodução capitalista da riqueza, compondo as estratégias dos agentes econômicos no correto investimento de capital sobre a terra, de modo a assentir a capitalização das rendas, em que pesem as dificuldades de "...asegurar el incremento de este papel positivo y en restringir al mismo tiempo el negativo" (HARVEY, 1990 [1982], p. 363). Afinal, a terra, diferentemente do trabalho social, não é capaz de produzir valor sozinha, embora muito dos estudos da economia política e que se debruçaram sobre a teoria dos preços aplicada ao mercado de terras tenha desconsiderado as origens mais profundas da produção da riqueza social através desse meio de produção.

Ora, a mentalidade moderna do proprietário se coloca como uma resultante dessa imperiosa necessidade de se libertar a terra de toda e qualquer barreira que possa vir a embotar o livre desenvolvimento das forças produtivas - que, a rigor, corresponde ao livre exercício da vontade de que falava Hegel (1997 [1820]), em sua crítica à forma dominial e exterior da propriedade em Kant. Por isso, é preciso retirar do proprietário de terras qualquer poder direto sobre o uso da terra, sobre a força de trabalho empregada e sobre o capital adiantado no investimento (HARVEY, [1982] 1990). Para tal, uma indenização poderia ser estipulada pelo Estado ou, como insistiu Stuart Mill (1996 [1848]), poder-se-ia, via legislação, “... converter toda a classe dos donos de terra em detentores de fundos ou pensionistas...", além de "...transformar os arrendatários em proprietários" (p. 290). Daí foram formuladas e implementadas as leis que permitiram a

\footnotetext{
9Em relação a esse papel positivo, diz-nos Harvey (1990 [1982]): "De hecho, uno de los triunfos del capitalismo ha sido obligar a los dueños de tierras a desempeñar ese papel positivo [usar o capital que estes centralizam através da apropriação da renda fundiária] como una condición para su supervivencia. Empero, aquí aparece una línea mucho más general de lucha de clases, porque los dueños de tierras no estaban necesariamente a usar el poder del dinero que habían centralizado simplemente como dinero que se pone en circulación como capital. A fin de cuentas, el poder social del dinero estaba destinado a dominar sobre el poder social da tierra. El uso de la tierra para adquirir dinero había sido durante largo tempo la meta de los sectores más dinámicos de terratenientes con los arrendadores de todos tipos. Los terratenientes perdieron su papel autónomo e independiente y se transformaron necesariamente em una fracción del propio capital. Las luchas históricas entre los terratenientes y los industriales em la Inglaterra del siglo XIX, y las luchas semejantes que continúa habiendo en muchas otras partes del mundo, deben verse contra el telón de fondo de esa transformación necesaria que asimila a ambos dentro de la estructura de la circulación del capital a interés" (p. 369)
} 
expropriação final das terras da Coroa e da Igreja, bem como os últimos resquícios das possessões utilizadas pela pequena indústria doméstica rural em terras inglesas $^{10}$.

Guardadas as diferenças históricas acerca do processo de desenvolvimento capitalista, no interior do qual as diversas configurações da atualização da propriedade da terra podem ser verificadas enquanto respostas para com ele se defrontar, uma característica geral que passou a nortear a atuação desses agentes econômicos em relação à propriedade é, tal como elucida Harvey (1990 [1982]), a crescente tendência a tratá-la "...como un puro bien financiero" (p. 350). Essa característica se revela no seu casamento com a forma superior da propriedade, permitindo que tais agentes possam ver na terra a possibilidade de the dar um emprego "social".

$\mathrm{Na}$ esteira de uma série de críticas ao direito absoluto e exclusivo de propriedade, motivadas pela expansão das correntes políticas socialistas no Ocidente europeu, tornou-se preciso criar (e atualizar, quando necessário) o arcabouço jurídico que forjasse as salvaguardas institucionais para dois importantes aspectos, articulados entre si. 0 primeiro, retirar da propriedade (não só a fundiária) a qualidade de ser tão somente um direito subjetivo do proprietário, obrigando-o a dotá-la de uma função social que implicasse o contributo na reprodução da riqueza social. O segundo aspecto, consistia, no limite, na criação de um arcabouço jurídico e institucional com o fito de inscrever a propriedade no mercado de terras, tornando-o uma forma específica da circulação do capital a juros e apropriação das rendas fundiárias, além de fazer destas uma forma de capital fictício (HARVEY, 1990 [1982]).

Tratemos rapidamente das origens dessa regulação, sem, por ora, abordarmos os embates contidos nas posições políticas sobre a regulação jurídica da propriedade.

Embora possamos remeter ao crepúsculo do século XVIII alguns poucos registros acerca das posições políticas simpáticas às utilizações econômicas com "fins sociais" da propriedade ${ }^{11}$, a sua efetividade jurídica pertence aos primeiros anos do século $\mathrm{XX}$, com as Cartas Constitucionais elaboradas e promulgadas após o fim da Primeira Guerra Mundial. Nelas se faziam presentes, juntamente com os direitos individuais e políticos, as declarações dos direitos sociais. Junto aos princípios de igualdade material - direta e indiretamente providos pelo Estado - encontrava-se a função social da propriedade

\footnotetext{
"'Assim, à expropriação dos camponeses que trabalhavam antes por conta própria e ao divórcio entre eles e seus meios de produção correspondem a ruína da indús-

tria doméstica rural e o processo de dissociação entre a manufatura e a agricultura. E só a destruição da indústria doméstica rural pode proporcionar ao mercado interno de um país a extensão e a solidez exigidas pelo modo capitalista de produção" (MARX, 1998 [1867], L. 1, v. 2, p. 869. Os grifos são nossos).

"Tais registros, embora bastante localizados, remetem à elaboração da Constituição francesa de 1793. Aqui, os debates sobre a função social da propriedade se situaram nas relações entre trabalho e propriedade, dadas as preocupações em se buscar maneiras de incorporar o proletariado à sociedade burguesa sem que se tocasse de modo radical na sua relação social de produção fundamental.
}

como parte dos dispositivos sobre a ordem social e econômica, os quais orientariam a intervenção estatal nos domínios econômico e social.

Exemplos notáveis dessas Cartas são a Constituição mexicana e a Constituição de Weimar ${ }^{12}$. Tarso de Melo (2012) assinala que a grande inovação desta última concerniu ao tratamento no âmbito do direito constitucional de questões até então circunscritas ao âmbito privado. A propriedade privada deveria ser empregada na busca do "pleno desenvolvimento social" na realização da atividade econômica, sem, contudo, que ela se desse em detrimento dos direitos fundamentais do cidadão - no caso específico, o direito civil de propriedade. De acordo com Gilberto Bercovici (2004), a Constituição de Weimar buscou legitimar a república alemã por meio de princípios democrático-liberais e do chamado "Estado social", com o fito de incorporar a classe trabalhadora ao Estado com base na emancipação política e na igualdade jurídica de direitos.

Esse arcabouço está hoje em dia consagrado nas Constituições mundo afora e nas legislações infraconstitucionais diversas, não sendo diferente no $\mathrm{Brasil}^{13}$. $\mathrm{Na}$ nossa história constitucional, a função social da propriedade só veio a aparecer como um princípio na Constituição Federal de 1988, com sua regulamentação tendo ocorrido bem mais tarde, no ano de 2001, com a aprovação do Estatuto da Cidade (Lei n. 10.257).

$\mathrm{Na}$ Constituição, a função social da propriedade acha-se presente em quatro momentos. 1) No Título II, "Dos Direitos e Garantias Fundamentais", em seu Capítulo I, intitulado "Dos Direitos e Deveres Individuais e Coletivos", tal "função social" aparece no Inciso XXIII do Artigo $5^{\circ}$, que trata da "Igualdade perante a lei"; 2) No Título VII, "Da Ordem Econômica e Financeira", em seu Capítulo I, intitulado "Dos Princípios Gerais da Ordem Econômica", a "função social" da propriedade aparece no Inciso III do Artigo $170^{\circ}$, que trata da "ordem econômica, fundada na valorização do trabalho humano e na livre iniciativa"; 3) No Capítulo II do mesmo Título VII, em seu Artigo $182^{\circ}$ (cuja regulamentação, ao lado do Artigo $183^{\circ}$, é dada pelo Estatuto da Cidade), cujo Parágrafo $2^{\circ}$ estabelece que a "propriedade urbana cumpre sua função social quando atende às exigências fundamentais de ordenação da cidade expressas no plano diretor"; e 4) No Capítulo III, ainda no mesmo Título VII, desta feita em seus Artigos $184^{\circ}$ e $186^{\circ}$, os quais estabelecem, respectivamente, a competência da União para desapropriar o imóvel rural

\footnotetext{
${ }^{2}$ Afora algumas diferenças residuais dos termos utilizados nos dois textos constitucionais, o instituto da propriedade e sua função social possuem as mesmas raízes. Na Constituição mexicana (datada de 1917), em seu artigo 27, aduz-se que: "A Nação terá, a todo tempo, o direito de impor à propriedade privada as determinações ditadas pelo interesse público (...)". Já na Constituição de Weimar (datada de 1919), em seu artigo 153, aduz-se que "A propriedade obriga e seu uso e exercício devem ao mesmo tempo representar uma função no interesse social" (LEONETTI, 1997)

${ }^{13} \mathrm{Em}$ verdade, no ordenamento jurídico brasileiro, o instituto da função social da propriedade aparece pela primeira vez na Constituição Federal de 1934, em seu art. 113, n. 17 , em que a garantia do direito de propriedade não poderia se dar contra o interesse social ou coletivo
} 
que "não esteja cumprindo sua função social", e os critérios e graus de competência estabelecidos em lei para o "uso racional e adequado" da propriedade em relação aos "recursos naturais" e a observância das disposições que regulam as relações de trabalho.

Já no Estatuto da Cidade, particularmente no Capítulo 1 , art. $1^{\circ}$, se "estabelece normas de ordem pública e interesse social que regulam o uso da propriedade urbana em prol do bem coletivo, da segurança e bem-estar dos cidadãos, bem como do equilíbrio ambiental". Com base nessas normas, 0 art. $2^{\circ}$ estabelece que as políticas urbanas teriam "...por objetivo ordenar o pleno funcionamento das funções sociais da cidade e da propriedade urbana".

Ainda que inscritos dentro de uma tímida plataforma reformista, originada da condensação dos enormes conflitos de interesse que perpassaram a constituinte de 1988, não podemos descurar a importância das funções sociais da propriedade e da cidade como princípios constitucionais e paradigmas daquilo que Edésio Fernandes (2013) denomina "nova ordem jurídico-urbanística" e "nova ordem institucional"14, ambas expressas no Estatuto da Cidade. Ademais, a presença de tais princípios na Constituição de 1988 não foi uma bagatela histórica, e sim o resultado de lutas e reivindicações que remetem aos anos 1960, nos embates em torno da Reforma Urbana, e que culminaram na Emenda Popular da Reforma Urbana, a qual foi parcialmente incorporada aos artigos 182 e 183 da Constituição Federal.

Porém, como sublinha Fernandes (2013), tais conflitos de interesse não poderiam chegar até os dias atuais encerrando-se apenas no formalismo jurídico, o qual orientaria a disputa sobre o dever ser do "controle jurídico do desenvolvimento urbano". Não obstante o direito civil insista em ser o pressuposto das decisões jurídicas (por exemplo, no que toca às utilizações da propriedade), não raro se sobrepondo ao direito público e seu ramo urbanístico (e ao Estatuto da Cidade e às leis federais que o complementam), a juridicização das lutas urbanas possuiria limites. Por isso, uma profunda renovação da mobilização sociopolítica em torno das questões fundiárias, urbanas, habitacionais e ambientais teria de estar no campo de preocupações dos diversos movimentos sociais e dos grupos de apoio versados com a agenda da reforma urbana e do "direito à cidade".

Para Fernandes (2013), essa perspectiva seria um passo importante no combate à "descrença", da parte desses movimentos sociais e grupos de apoio, com o Estatuto da Cidade e com a própria agenda da reforma urbana e do "direito à cidade". Tal descrença careceria

${ }^{14}$ No tocante a essa nova ordem institucional, Fernandes (2013) faz menção à criação na esfera federal do Ministério das Cidades, em 2003; a convocação de Conferências Nacionais/Estaduais/Municipais das Cidades, bienalmente desde então: a instalação e a atuação do Conselho Nacional das Cidades; a ação da Caixa Econômica Federal; além dos diversos planos e programas federais, como o Plano de Aceleração do Crescimento (PAC) e o Programa Minha Casa, Minha Vida (PMCMV). de ser substituída por um "otimismo cauteloso", em que pese a necessidade de ser considerada nas suas dimensões "culturais e sociopolíticas". Afinal, a percepção dos setores sociais aludidos se alimentaria, dentre vários outros fatores, da verificação do avanço daquilo que o autor chama de "processos de especulação imobiliária" e de "gentrificação de áreas" nas principais metrópoles brasileiras, cuja ocorrência, de fato, aumentou pari passu às intervenções urbanísticas estatais e empreendimentos privados produzidos para os eventos esportivos ocorridos recentemente no Brasil.

Vale acrescentar que a importância do princípio da função social da propriedade (e da cidade) se revela bastante candente, sobretudo em uma formação social como a brasileira, no transcurso da qual se logrou generalizar relações de propriedade sem, contudo, generalizar as formas de acesso a ela. No entanto, julgamos imprescindível discutir, ainda que em linhas gerais, o fenômeno da presença de imóveis subutilizados, seja no campo ou nas aglomerações urbanas, e que se traduziria, no entendimento dos movimentos sociais de luta pela moradia (e de muitos estudiosos da "questão urbana"), no termo "especulação imobiliária". A nosso ver, ao lançarem mão deste termo para denunciar a subutilização de imóveis urbanos ou rurais, tais movimentos sociais passariam ao largo da estratégia mais adequada para continuar exigindo a efetividade dos mecanismos jurídico-institucionais e a difícil aplicação dos instrumentos jurídico-urbanísticos criados a partir do Estatuto da Cidade, notadamente aqueles que combatem a subutilização ou a vacância e que limitariam o caráter exclusivamente individual do direito de propriedade -, como o IPTU Progressivo e o Direito de Preempção.

Faremos essa discussão nos valendo de um exemplo empírico na metrópole de Belo Horizonte, cuja realidade concreta é a síntese de algumas das determinações que trazemos neste ensaio: a chamada "região do Isidoro" e alguns aspectos da trajetória da mobilização das propriedades na área.

As articulações privadas face aos entraves/possibilidades para a capitalização das rendas fundiárias: as Operações Urbanas do Isidoro de 2000 e 2010

Localizada no extremo norte de Belo Horizonte, cujos limites se fazem com o município de Santa Luzia, a "região do Isidoro" é considerada a última área privada não parcelada ${ }^{15}$ da capital mineira. Desde julho de 2013, essa área vem sendo palco daquele que talvez seja o maior conflito fundiário do Brasil, com a presença de três ocupações residenciais (Esperança, Vitória e Rosa Leão) que

${ }^{5}$ Até o ano de 2010, a área era classificada como uma Zona de Proteção Ambiental (ZPAM) e Zona de Proteção (ZP), o que a caracterizava como área de preservação de mananciais regulada por um zoneamento restritivo. 
totalizam, segundo os movimentos sociais que estão à sua frente, cerca de 8 mil famílias.

Com um histórico que remonta às primeiras décadas desde a inauguração de Belo Horizonte, as propriedades que compõem a "região do Isidoro" foram sendo adquiridas por Hugo Furquim Werneck, médico fluminense que viera para a capital tratar de uma tuberculose pulmonar, mas que ali acabou por se estabelecer. Entusiasmado com as características climáticas de Belo Horizonte propícias ao tratamento da tuberculose, segundo a medicina da época - e, ao que parece, tendo visto a possibilidade de negócios envolvendo o processo de internação e tratamento daquela enfermidade, Hugo Werneck construiu e inaugurou na região, no ano de 1929, um dos mais modernos sanatórios do País, cujo funcionamento se deu até 1975.

Após a morte de Hugo Werneck, em 1935, a gestão dos ativos fundiários (que, à época, chegaram a totalizar 596 hectares) e do próprio sanatório ficaram a cargo da empresa Granja Werneck S.A., criada no ano seguinte por seu filho mais velho, após o processo de partilha da propriedade, decorrente da morte da esposa de Hugo Werneck.

Desde então, entre algumas desapropriações pelo Poder Municipal e vendas esporádicas de parte das terras, os familiares de Hugo Werneck, por meio da Granja Werneck S.A., têm tentado redefinir as modalidades de mobilização da propriedade na "região do Isidoro". Uma primeira tentativa mais diligente ocorreu no ano 2000, através de uma Operação Urbana Simplificada, instituída pela Lei Municipal n. 8.137/2000. O instrumento tinha por objetivo, num prazo de seis anos e realizado em parceria entre o município e empreendedores privados, "...promover a ocupação ordenada da região do Isidoro, através da implantação de sistema viário e equipamentos que dotem a região da infraestrutura necessária ao seu desenvolvimento econômico, ambiental e urbano".

Entretanto, como bem apontado por Daniela Abritta Cota (2010), a tentativa de se promover a "ocupação ordenada" da "região do Isidoro" acabou não se concretizando. E isso porque a lei da Operação Urbana teria sido aprovada "...sem que houvesse um acordo prévio entre os interesses públicos e particulares envolvidos; ou seja, não havia garantia de que a parceria fosse efetivada" (COTA, p. 306, grifo da autora). Somado a esse fato, ainda segundo a autora, o poder municipal não realizou os investimentos em infraestruturas físicas que possibilitassem a atração dos capitais para produzir os empreendimentos na área, tornando-os inviáveis, pelo menos naquele momento.

Assim, a obsolescência das infraestruturas físicas de transportes anteriores na porção norte - tida como de ocupação heterogênea e "desordenada" - era também um fator primordial a ser revertido, de modo que as no- ções de acessibilidade e fluidez (pelo menos em tese) se tornassem os suportes materiais e simbólicos para a viabilidade dos negócios engendrados a partir da operação urbana de 2000. Alguns dos interesses que se voltavam para a região naquele ano já traziam consigo propósitos de mobilização da propriedade orientados pelos circuitos mais desenvolvidos das relações de produção capitalistas, formas superiores em relação às modalidades de rentismos conjugadas à ocupação original da porção norte de Belo Horizonte, mas eram insuficientes para gerar a sinergia dos negócios. Com efeito, a presença dessas infraestruturas físicas poderia alavancar os elementos do capital fixo de longa duração, necessários à chegada de novos empreendimentos e a construção da representação ideológica que positivaria a porção norte como o "mais novo vetor de desenvolvimento" da capital.

Porém, a provisão dessas infraestruturas físicas não poderia ser feita pelos agentes privados (capitais construtor e incorporador) de maneira isolada, dado que envolvem grandes somas de capital a ser imobilizado. $\mathrm{E}$ por ser também onerosa para o Estado, a produção de infraestruturas físicas não se traduz no resultado das requisições de um capital individual, e sim de uma tomada de decisões ocorrida em consonância com determinados agentes privados - e apenas quando estes são tornados estratégicos nas reestruturações urbano-metropolitanas. E essa tomada de decisões passa, ainda que não exclusivamente, pelos resultados da produção de uma demanda social por solo urbano, decorrente das ações desses agentes e do seu consumo pelos grupos solváveis, bem como as implicações dessa demanda na estruturação dos preços do solo.

Para que essa condição possa de alguma maneira se realizar, é preciso que esses agentes privados estejam em concorrência na região onde vão atuar, tornando-se os demandantes das terras, induzindo a sua escassez e justificando assim a alocação dos investimentos estatais, inclusive para aperfeiçoar os meios para a circulação do capital no ambiente construído. Como então não havia atrativos que permitissem essa demanda em profusão e através de investimentos com intensidade de capital, os "alicerces" da Operação Urbana do ano 2000 não puderam, naquele momento, ser erguidos. E não puderam porque, ao se impor como racionalidade operadora das estratégias dos agentes econômicos da produção do ambiente construído, a presença da renda fundiária também impõe que somente as utilizações mais rentáveis sejam possíveis.

Essa busca por rentabilidade acima da média - e, obviamente, pelas vantagens competitivas que lhe forneçam suporte - ocorre por intermédio daquilo que Harvey (1990 [1982]) chamou de busca por "situações superiores" -, as quais normalmente são associadas às vantagens tecnológicas. No concernente a tais situações, 
mormente as vantagens competitivas por elas proporcionadas e os elementos necessários à sua ocorrência, o autor em tela explica que:

La ventaja de determinada situación para el capitalista individual depende del costo del capital constante y variable, de la transportación a los mercados con suficiente demanda efectiva, del costo del capital a interés, el costo y disponibilidad de una serie de servicios subordinados, así como el precio de la tierra. (HARVEY, 1990 [1982], p. 391)

No transcurso histórico no qual o espaço entrou na reprodução das relações sociais, a produção de situações superiores progressivamente foi se tornando mais intensa e dinâmica, pois faz parte dos artifícios para se diminuir custos de produção e de circulação e se reduzir o tempo de rotação do capital em geral. Arranjos institucionais são formulados, aprimorados e implementados com vistas a gestar o ambiente adequado de negócios aos capitais interessados em se instalarem em determinado lugar ou região ou país ${ }^{16}$. Enormes disputas se estabelecem tanto entre as diferentes escalas assinaladas quanto entre os capitalistas individuais, com o intuito de se cercar das vantagens competitivas imprescindíveis à obtenção dos lucros extraordinários. Essa é uma dimensão daquilo que Harvey (1990 [1982]) denominou "desenvolvimento geográfico pouco uniforme" do capitalismo, conceito que ajuda a apreender, dentre outras nuances da mobilização do capital pelo espaço, os diferenciais no seu processo de capitalização. Advém daí, com todas as suas repercussões, o surgimento dos "vetores de expansão urbana", ligados aos investimentos do par setor "imobiliário"/capital portador de juros, da indústria, ou, ainda, o seu reverso necessário: o abandono de áreas inteiras pelos capitais outrora aí empregados.

Trata-se de características contemporâneas da circulação do capital pelo espaço que se revelam ainda mais sensíveis aos ritmos sumamente mais intensos das mudanças tecnológicas que possam propiciar incrementos constantes na materialidade do espaço - por exemplo, na produção das infraestruturas físicas. 0 acirramento da competição entre os agentes econômicos da produção das mercadorias - entre elas o ambiente construído urbano - impõe que a busca pelas situações superiores seja diretamente dependente da retirada (apenas temporária) dos obstáculos ao deslocamento espacial das mercadorias produzidas. Ademais, a produção de infraestruturas físicas, ao seguir os preceitos de integração espacial em ritmos e condições desiguais

${ }^{16}$ Ressalte-se, aqui, a Lei n. 9.514, que criou o Sistema de Financiamento Imobiliário $(\mathrm{SFI})$, apresentado como "complementar" ao já vigente Sistema Financeiro da Habitação (SFH). O principal intuito da Lei do SFI foi o de propiciar segurança jurídica aos agentes que utilizam o crédito imobiliário para suas operações (principalmente os investidores) e também fomentar a liquidez para os títulos securitizados. Essa lei foi de suma importância para a notável ampliação desse crédito imobiliário no Brasil a partir dos anos 2000 e também para o estreitamento das relações entre os mercados financeiros e a produção e o consumo do ambiente construído urbano (SANFELICI, 2013). Outro instrumento importante para a segurança jurídica das instituições financeiras foi o Patrimônio de afetação, cuja vigência se deu a partir da Lei n. 10.931, aprovada em 2004. nas diferentes escalas espaciais, universaliza - também de modo desigual - os pilares da troca e do valor de troca para os mais diversos recônditos da vida individual e social. Inscrevendo-se com maior ou menor voracidade no plano da cotidianidade, essa universalização materializada nas infraestruturas físicas a submete à temporalidade da circulação ampliada e da realização do mais-valor. Para Marx (2011 [1857-58]):

\begin{abstract}
Quanto mais a produção se baseia no valor de troca e, em consequência, na troca, tanto mais importantes se tornam para ela as condições físicas da troca - meios de comunicação e transporte. É da natureza do capital mover-se para além de todas as barreiras espaciais. A criação de condições físicas da troca (...) devém uma necessidade para o capital em uma dimensão totalmente diferente - a anulação do espaço pelo tempo. (p. 432)
\end{abstract}

Anos mais tarde, com a conjugação dos projetos da implantação do aeroporto industrial em Confins, da produção da "Linha Verde"17, da duplicação da avenida Antônio Carlos ${ }^{18}$, além da instalação da nova Sede Administrativa do Governo de Minas Gerais - projetos levados a cabo em meados da primeira década de 2000, como parte da viabilização do "vetor norte" de Belo Horizonte - criou-se um "fato novo" para que a "região do Isidoro" voltasse à pauta dos interesses dos capitais construtor, incorporador e dos proprietários fundiários da área. As novas possibilidades de ganhos econômicos faziam daquele patrimônio fundiário algo propício aos interessados em promover o seu parcelamento e materializar empreendimentos imobiliários de grande intensidade de capital. A articulação de momento entre os interesses em marcha levou aqueles agentes, explica Cota (2010), "...a procurar o Executivo na tentativa de viabilizar uma parceria que permitisse a utilização sustentável da área" (p. 306). A partir daí, uma nova proposta de operação urbana foi finalmente elaborada e aprovada, sob a forma de Emenda Aditiva ao Projeto de Lei n. 820/09, o qual tratava de alterações no Plano Diretor (Lei Municipal $n$. 7.165/1996) e na Lei de Parcelamento, Uso e Ocupação do Solo de Belo Horizonte (Lei Municipal n. 7.166/1996), e que reverberou na promulgação da Lei Municipal $n$. 9.959/2010.

Do que dissemos acima, pode-se depreender que os artifícios utilizados pelos proprietários fundiários da "região do Isidoro", bem como suas tentativas de articulação com os agentes econômicos (empresas construtoras e incorporadoras), esbarraram, na Operação Urbana de 2000, nas determinações concretas da metropolização de Belo Horizonte, particularmente na sua porção norte. Os interesses daqueles proprietários para mobilizar a propriedade na esteira das condições jurídicas e

Referência ao projeto viário lançado em 24 de maio de 2005 e concluído no ano seguinte pelo governo de Minas Gerais, cujo percurso envolve Belo Horizonte e a porção norte de sua região metropolitana.

${ }^{18}$ Trata-se de uma das avenidas arteriais de Belo Horizonte, cujo percurso liga a área central até a região da Pampulha, também localizada na porção norte da capital. 
institucionais propícias às redefinições da porção norte da metrópole, em fins da década de 1990 e na década seguinte, permitindo assim incrementos nos preços do solo, de modo a que pudessem se apropriar das rendas fundiárias, não se realizaram. Ao que parece, os representantes da Granja Werneck S.A. (os proprietários), sabedores de que sua atuação sem a aliança com agentes econômicos com claros interesses em investir na área repercutiria em nenhum controle sobre os determinantes dos preços do solo, ao mesmo tempo tentavam tornar viável algum negócio com boa rentabilidade na área, atuando nos bastidores do Poder Municipal. Além do mais, os intentos dos proprietários da área abarcavam, mas também queriam ir além da simples compra, parcelamento e venda de terras, voltados para as frações de baixos rendimentos (experimentado na década de 1980), justamente para construir condições propícias para tais incrementos nos preços do solo.

Daí nossa afirmação, no início desta seção: ao contrário do que normalmente se supõe, as propriedades da "região do Isidoro" não ficaram "paradas", fenômeno que se traduziria, para os movimentos sociais de luta pela moradia e para vários estudiosos da "questão urbana", no termo "especulação imobiliária". Samuel Jaramillo González (2010) explica que as mudanças temporais nos preços do solo, por normalmente tornarem possível o seu incremento, incentivam agentes econômicos como proprietários fundiários e os capitais construtor e incorporador a buscarem dele se apropriar, sob a forma de rendas fundiárias. E seria esse afã de se apropriar de tais incrementos que levaria à compra de terras com o objetivo de vendê-las em outro momento, prática à qual González chama de "especulação urbana". Porém, a especulação com terras, assim como a especulação com papéis, não pode ser analiticamente tratada como algo exterior à produção, mas como uma manifestação necessária e possível de processos universais nos quais estão presentes a produção, a realização e a distribuição do mais-valor. Obviamente, faz-se prudente cientificamente compreender a particularidade, isto é, a situação concreta de onde se parte - que, no nosso caso, é a "região do Isidoro". Aqui, a intenção de abarcar, mas também de ir além do movimento de compra, parcelamento e venda de terras, situado no nível da "especulação passiva", de acordo com González, implica participar da "especulação indutiva": participar da gestação e da apropriação dos incrementos mais substanciais dos preços do solo - logo, das rendas mais elevadas.

Malgrado os intentos de participar desses incrementos não tenham se realizado no tempo e na medida exatas vislumbradas pela Granja Werneck S.A., o principal ativo gerido pela empresa - a propriedade da área - sempre foi mobilizado. A nosso ver, a questão a ser compreendida concerne às metamorfoses nas modalidades da mobilização daquela propriedade, nos entraves colocados para tal, bem como na busca, por parte dos proprietários, das soluções que fossem consoantes aos seus interesses. No âmbito dessa mobilização, nunca esteve de fora a irrequieta busca por operações especulativas de largo alcance - leia-se a "especulação indutiva", nos termos de González. De acordo com este autor, essas operações atravessam os diferentes momentos da atuação dos agentes econômicos de peso, cujos capitais estão envolvidos com a urbanização. São operações não circunscritas à circulação, mas que abarcam o processo de produção do ambiente construído, passando pelo momento mais "irrisório" de compra e venda de terras para alcançar seus propósitos: dirigir e modular, dentro das possibilidades de que dispõem esses agentes econômicos, transformações mais profundas no processo de urbanização. Noutros termos, dirigir e modular "...la traducción sobre el espacio de los cambios referidos en los precios del suelo" (GONZÁLEZ, 2010, p. 210).

\section{Considerações finais}

Vimos que as tentativas de se dar uma orientação "progressista" às categorias da economia política como afirmamos ser o caso da função social da propriedade - não vêm deste século. Tal orientação já se fazia presente no século XIX, mesmo entre os representantes da burguesia (entre eles Stuart Mill), e se estendeu ao longo daquele século, adentrando o seguinte, sempre atualizada - não obstante carregada das mesmas ilusões jurídicas. Talvez a consequência mais patente dessa mesma orientação seja a sua coerência com o reformismo distributivista e o fortalecimento da máquina de Estado.

No âmbito das reivindicações do cumprimento da função social da propriedade, quando os movimentos sociais e grupos de apoio acusam determinados proprietários fundiários de não observarem aquele princípio e atuarem como "especuladores imobiliários" (a versão atual do proprietário "parasita"), põe-se em relevo a inocuidade da ênfase no caráter negativo da propriedade ${ }^{19}$, referido às barreiras por ela colocadas aos investimentos de capital e às restrições postas por patamares de capitalização situados na renda absoluta. Dessa ênfase decorre que se presta pouca atenção no quanto tal caráter negativo pode levar à positividade das utilizações da propriedade na articulação entre proprietários de terra e de capital, como no caso da "região do Isidoro", por nós apresentado acima.

Ainda assim, se não podemos nos furtar da crítica à

Nas palavras de Harvey (1990 [1982]): "Desgraciadamente gran parte de la polémica dirigida contra la renta de monopolio y la renta absoluta y contra el papel parasitario y superfluo del terrateniente en esas situaciones, se ha trasladado al análisis de la renta diferencial. Por tanto, se han subrayado los aspectos negativos de las intervenciones de la propiedad territorial, y se ha prestado poca atención al papel positivo de coordinar la corriente de capital a la tierra y a través de ella en formas que apoyan ampliamente la acumulación ulterior" (p. 364). 
crença na função social da propriedade, defınida por uma certa ordem jurídica e encampada pelo Estado, tampouco podemos decretar, de antemão, a indigência teórica e prática dos movimentos sociais que reivindicam o cumprimento daquele princípio em suas lutas urbanas.

As tensões que daí se sobressaem emergem de diferentes porções do espaço intrametropolitano e revelam, por um lado, quão árdua tem sido a busca dos movimentos sociais pelo amparo jurídico através das reivindicações, feitas às comissões de direitos humanos das Casas Legislativas e demais instâncias institucionais "competentes", da efetivação do princípio da função social da propriedade e das garantias fundamentais como a Dignidade da Pessoa Humana, contidas no texto Constitucional. Por outro lado, notamos a gestação de possibilidades concretas a partir das estratégias dos movimentos sociais, centradas nas ocupações residenciais, sobretudo quando se nota a formação de relações de reconhecimento e de pertencimento cada vez mais tenazes; a percepção, por parte de muitos ocupantes, de que a necessidade de luta pela moradia decorre de um padrão desigual de apropriação do espaço; de que é preciso de formas de organização política e comunitária construídas coletivamente, dentre outros aprendizados políticos.

Visto que o Estado não é uma instância neutra, mas, ao revés, é, por excelência, um campo aberto de conflitos, que as lutas sociais não podem deixar de vislumbrar atingir os pilares de seu edifício. Essa característica intrinsecamente conflitual do Estado moderno ocorre, de acordo com Joachim Hirsch (2010), não porque ele estaria "tomado" pelos representantes da burguesia, e sim porque, enquanto forma social, ele traz consigo, como uma de suas funções, aquela de estruturar as relações sociais de produção. Apesar de individualizar os conflitos sociais, retirar-lhes das relações de classes e deslocá-los para a esfera do reconhecimento formal e procurar dirimi-los, a forma política estatal - e todo o arcabouço jurídico que pavimenta a sua ação - debate-se com as contradições próprias a tais funções, por ela assumidas na modernidade.

E o princípio da função social da propriedade, no tocante às interpretações jurídicas que este recebe, contém e expressa o campo aberto de conflitos que chamamos a atenção acima. Um desses conflitos reside na dogmatização daquelas interpretações, reafirmando a figura do proprietário e do caráter eminentemente patrimonial que move suas definições acerca do direito de propriedade. Outro conflito - o qual, obviamente, choca-se com o anterior - concerne à realização concreta do princípio, mais próxima da ideia de satisfação das diferentes necessidades sociais que compõem a utilização da terra como meio de produção e meio de vida e que tendem a fazer parte daquilo que os movimentos sociais (urbanos e agrários) reivindicam.

Do primeiro conflito se desdobram, por exemplo, as pressões pela realização do ambiente adequado de negócios, marcado por aquilo que é chamado de segurança e previsibilidade da norma, e imprescindível para que os capitais construtor/incorporador possam atuar em condições favoráveis na produção e na circulação do ambiente construído urbano. No Brasil, o ordenamento jurídico que permite a reinscrição da propriedade nos circuitos de valorização do valor se divide em dois, embora ambos não estejam desvinculados um do outro. 0 primeiro deles, a regulamentação do princípio da função social da propriedade e da função social da cidade, com a aprovação do Estatuto da Cidade; o segundo, a criação do Sistema de Financiamento Imobiliário (Lei Federal n. 9.514/1997), complementado pela Lei do Patrimônio de Afetação (10.931/2004).

O segundo conflito, no interior dos quais se move a função social da propriedade, contém não só as lutas para que as interpretações jurídicas retirem dos movimentos sociais o epíteto de "quadrilhas" e que as ocupações de terra deixem de ser vistas como "esbulho possessório", mas também as lutas pelo cumprimento daquele princípio.

Portanto, através da identificação das contradições próprias às funções do Estado, deve-se compor um debate atento ao acirramento dos conflitos decorrentes daquelas contradições. E um debate que não se proponha apenas a lamentar as aporias colocadas à construção da emancipação humana ou que se contente com uma suposta prevalência que deveria ser dada às interpretações jurídicas em torno da propriedade. E, para tal, os movimentos sociais que se municiam da via jurídica para combater o dogmatismo devem estar atentos à maneira pela qual a legalidade atualiza as derivações necessárias ao econômico e à economia política. Noutros termos, os movimentos devem estar atentos à maneira como a legalidade determina a formação do escopo institucional do qual o Estado se vale para reafirmar a propriedade e suas relações sociais no âmbito da urbanização contemporânea. 
BERCOVICI, G. (2004) Constituição e estado de exceção permanente: a atualidade de Weimar. Rio de Janeiro: Azougue. 275 p.

COTA, D. A. (2010) Parceria público-privada na política urbana brasileira recente: reflexões a partir da análise das operações urbanas em Belo Horizonte. $430 \mathrm{f}$. Tese (Doutorado em Geografia) - Instituto de Geociências da Universidade Federal de Minas Gerais, Belo Horizonte, 2010.

FERNANDES, Edésio. (2013) Estatuto da Cidade, mais de 10 anos depois: razão de descrença, ou razão de otimismo? Revista UFMG, Belo Horizonte, V. 20, n. 1, jan./jun., p. 212-233.

GONZÁLEZ, S. J. (2010) Hacia una teoría de la renta del suelo urbano. Bogotá: Universidad de los Andes, Facultade de Economía, CEDE, Ediciones Uniandes.

HARVEY, D. (1990 [1982]) Los límites del capitalismo y la teoría marxista. México: Fondo de Cultura Económica.

HEGEL, F. (1997 [1820]) Princípios da filosofia do direito. São Paulo: Martins Fontes, 329 p.

HIRSCH, J. (2010) Teoria materialista do Estado: processos de transformação do sistema capitalista de Estados. Rio de Janeiro: Editora Revan. 326 p.

LEFEBVRE, H. (2008 [1972]) Espaço e política. Belo Horizonte: Editora UFMG, 190 p.

LEONETTI, C. A. (1999) Função social da propriedade: mito ou realidade? Novos Estudos Jurídicos, Itajaí, Ano V, n. 8, p. 17-26.

MARX, K. (2004 [1844]) Manuscritos econômico-filosóficos. São Paulo: Boitempo Editorial, 175 p. (2011 [1857-58]) Grundrisse. Manuscritos econômicos de 1857-58. Esboços da crítica da economia política. São Paulo: Boitempo editorial. 788 p.

(1998 [1867]) O capital. Crítica da economia política. Rio de Janeiro: Civilização Brasileira. L. I, v. 2. 364 p.

(1974 [1894]) O capital. Crítica da economia política. Rio de Janeiro: Civilização Brasileira. L. III, v. 4.378 p.

MELO, T. de. (2012) Direito e ideologia: um estudo a partir da função social da propriedade rural. São Paulo: Outras Expressões/Dobra Editorial. 192 p.

RUBIN, I. I. (2014 [1989]) História do pensamento econômico. Rio de Janeiro: Editora UFRJ, 524 p.

SANFELICI, D. M. (2013) A metrópole sob o ritmo das finanças: implicações socioespaciais da expansão imobiliária no Brasil. 308 f. Tese (Doutorado em Geografia Humana) - Faculdade de Filosofia, Letras e Ciências Humanas da Universidade de São Paulo, São Paulo, 2013.

STUART MILL, J. (1996 [1848]) Princípios da economia política com algumas de suas aplicações à filosofia social. São Paulo: Nova Cultural, 479 p. 